УДК 811.111 '42:82-312.4Кінг

DOI https://doi.org/10.26661/2414-1135-2021-84-12

\title{
МОВНІ ЗАСОБИ ВИРАЖЕННЯ ЕМОЦІЙНОГО СТАНУ ГЕРОӤВ У РОМАНІ СТІВЕНА КІНГА «КЛАДОВИЩЕ ДОМАШНІХ ТВАРИН»
}

\author{
Доніна А. О. \\ магістр кафедри теорії та практики перекладу \\ Національний університет «Запорізька політехніка» \\ вул. Жуковського, 64, Запоріжжя, Украӥна \\ orcid.org/0000-0002-4803-183X \\ doninaanastasia9@gmail.com \\ Лут К. А. \\ кандидат філологічних наук, дочент, \\ дочент кафедри теорії та практики перекладу \\ Начіональний університет «Запорізька політехніка» \\ вул. Жуковського, 64, Запоріжжя, Україна \\ orcid.org/0000-0002-9842-3540 \\ katerinalut@gmail.com
}

Ключові слова: література жахів, жанрові особливості, емоиії, лінгвостилістичні засоби, саспенс, страх.
Стаття присвячується вивченню специфіки передачі емоцій мовними засобами в романі Стівена Кінга «Кладовище домашніх тварин». У лінгвістиці все більше уваги приділяється розгляду особливостей взаємозв'язку мови й емоцій. Визначення індивідуально-авторських способів вираження емоційних станів людини в романах жанру жахів актуальне для дослідження.

Стівен Кінг є одним із найвідоміших американських письменників, чиї твори змушують кров стигнути в жилах. Приналежність роману «Кладовище домашніх тварин» до жанру хорор літератури детермінує домінування негативних емоцій. Розглядаючи емоції жаху, страху, тривоги й невизначеності як основні жанротвірні елементи, було виявлено, що їх реалізація в художньому тексті відбувається крізь призму описів емоційних станів персонажів. Також було визначено основні прояви досліджуваних емоцій і проілюстровано їх мовне вираження в романі. Ми з'ясували, що вираження емоційного стану героїв твору Стівена Кінга досягається комплексом лінгвостилістичних засобів. Описуючи характерні психофізіологічні емоційні реакції, письменник використовує епітети, метафори, персоніфікації, повтори, паралелізм, умовчання, риторичні питання. Найчастіше Стівен Кінг експлікує емоційний стан персонажа твору через такі фізіологічні зміни, як заціпеніння, прискорене серцебиття, підвищення потовиділення, похолодання кінцівок, поява сирот тощо. Крім того, було виявлено широке використання соматизмів. Лінгвостилістичні засоби відіграють неабияку роль у творі, адже за їх допомогою автор майстерно зображує почуття та переживання героїв твору. Вони створюють психоемоційне тло твору, а також дозволяють читачеві переживати події разом із його героями, глибше пізнаючи кожного 3 них. Опис емоційного стану героїв допомагає досягти емпатії з боку реципієнта. Автор залучає читача до активного співпереживання героям, відбувається емоційне включення читача в текстову дійсність. 


\title{
LANGUAGE EXPRESSION OF CHARACTERS' EMOTIONAL STATE IN THE NOVEL "PET SEMATARY" BY STEPHEN KING
}

\author{
Donina A. O. \\ Master Student at the Department of Theory and Practice of Translation \\ Zaporizhzhia Polytechnic National University \\ Zhukovskoho str., 64, Zaporizhzhia, Ukraine \\ orcid.org/0000-0002-4803-183X \\ doninaanastasia9@gmail.com \\ Lut K. A. \\ Candidate of Philological Sciences, Associate Professor, \\ Associate Professor at the Department of Theory and Practice of Translation \\ Zaporizhzhia Polytechnic National University \\ Zhukovskoho str., 64, Zaporizhzhia, Ukraine \\ orcid.org/0000-0002-9842-3540 \\ katerinalut@gmail.com
}

Key words: horror literature, genre features, emotions, linguistic and stylistic means, suspense, fear.
The article studies the specificity of conveying emotions by language means in Stephen King's novel "Pet Sematary". There is an increasing attention to studying the peculiarities of the relationship between language and emotions in linguistics. Determination of individual author's ways of expressing human emotional states in horror literature is relevant for research.

Stephen King is one of the most famous American writers whose works make reader's blood run cold. The fact that the novel "Pet Sematary" belongs to the genre of horror literature determines the dominance of negative emotions. Horror, fear, anxiety and uncertainty as the main genre elements find their way to the literary texts through the prism of the descriptions of the main characters' emotional states. Moreover, the research helped to identify the main manifestations of the studied emotions and illustrate their language expression in the novel. We found out that Stephen King achieves the expression of the characters' emotional state through a complex of linguistic and stylistic means. Describing characteristic psychophysiological emotional reactions, the writer uses epithets, metaphors, personifications, repetitions, parallelism, aposiopesis, rhetorical questions. Most often Stephen King expresses the emotional state of the character through physiological changes, such as numbness, heart palpitations, increased sweating, cold extremities, the appearance of goose bumps, etc. In addition, the widespread use of somatisms was found.

Linguistic and stylistic means play a significant role in the novel, because with their help the author skillfully depicts the feelings and experiences of the characters. They create the psychoemotional background of the work, and also allow the reader to experience events together with the characters, getting to know each of them better. Description of the characters' emotional state helps to achieve the recipient's empathy. The author attracts the reader to active empathy with the characters, and the reader is emotionally included in the textual reality.
Постановка проблеми. Література жахів $\epsilon$, без сумніву, одним із найпопулярніших жанрів сьогодення. Беручи свій початок у стародавніх ритуалах i доісторичних культах, вона проникла в казки й пісні, знайшла відбиття в готичних лицарських романах і зараз продовжує бентежити розум і лоскотати нерви читачів. Найбільш пара- доксальна й суперечлива літературна форма, яка нікого не залишає байдужим, приваблює своєю містичністю, надприродністю та незвичайністю.

«Королем» сучасної літератури жахів заслужено називають С. Кінга. Його твори - це не просто розповіді про типових для жанру жахів монстрів. У своїх творах він порушує важливі 
філософські й соціальні проблеми. Письменник майстерно описує емоції та психологічний стан звичайних людей - героїв його творів, чим змушує читача співпереживати, хвилюватися й відчувати той жах, який охоплює персонажів.

Незважаючи на те, що вивченню проблеми мовної експлікації емоцій присвячено багато робіт (І.В. Арнольд, Н.Д. Арутюнова, О.М. Вольф, М.В. Гамзюк та інші), деякі питання ще залишаються не досить розкритими. До них належать індивідуально-авторські способи вираження емоційних станів людини в романах жанру жахів, яким і буде присвячено дослідження.

Метою статті $\epsilon$ виявлення способів мовної експлікації емоційного стану персонажів у жанрі літератури жахів. Об'сктом дослідження є роман Стівена Кінга «Кладовище домашніх тварин». Предметом дослідження виступають лінгвостилістичні засоби в романі американського письменника Стівена Кінга «Кладовище домашніх тварин».

Виклад основного матеріалу дослідження. У мовознавчих студіях останніх років значна роль приділяється дослідженням, що пов'язані з вираженням емоцій у художніх творах та їх безпосереднім впливом на реципієнта. Література жахів за своєю природою належить до тих жанрів, що реалізуються за формулою: емоції персонажів = відгук читачів [1, с. 14]. Прагматична спрямованість жанру визначається створенням атмосфери саспенс i напруженого очікування, що досягається шляхом максимального залучення читача в драматичні події твору. Мета використання такого виду тривоги в літературі - зробити так, щоб читачі переймалися долею героїв і формували до них емпатію [2, с. 311].

Проблема відтворення людських емоцій i почуттів завжди викликала інтерес науковців. Так, В. Джемс під терміном «емоція» розуміє «психічні відбиття фізіологічних змін» [3]. А.П. Сєдих пов'язує емоції 3 прагненням до задоволення потреб і визначає їх як суб’єктивні реакції людини й тварин на вплив внутрішніх і зовнішніх подразників, які проявляються у вигляді задоволення або незадоволення, радості, страху тощо. Як реальні, так і уявні ситуації можуть викликати емоції $[4$, c. 110]. Емоції персонажів у художній літературі спостерігаються читачем не прямо, а через спеціальні емотивні знаки мови, тобто вони кодуються мовними знаками [5, с. 229].

У літературі жахів значна частина сюжету припадає саме на опис внутрішніх станів і переживань героїв. Як правило, вони переживають цілий спектр емоцій, більшість 3 яких негативні: сум, занепокоєння, тривога, невизначеність, напруга, страх тощо.

Було визначено, що у творі С. Кінга «Кладовище домашніх тварин» використовуються такі лексеми для позначення психологічного стану героїв: fright (переляк), anxiety (тривога), dread (страх, жах), alarm (тривога), danger (небезпека), apprehension (побоювання), horror (жах, страх), terror (жах), panic (паніка) тощо. Також було з'ясовано, що основними фізіологічними проявами досліджуваних емоцій є заціпеніння, прискорене серцебиття, підвищення потовиділення, похолодання кінцівок, поява сирот тощо.

Головними героями роману є доктор Луїс Крід, його дружина Речел та їхні діти: п'ятирічна дочка Еллі й дворічний син Гейдж. Вони переїжджають у новий будинок у Ладлоу. Здавалося б, їх чекає щасливе безтурботне життя, однак це не так. Уже на початку твору з'являються передвісники майбутньої біди. Безпричинна тривога охоплює Луїса одного вересневого дня. Із сином на руках він дістався сходового майданчика, коли його охопило передчуття жахливої майбутньої пітьми:

What's wrong? he wondered, confused and frightened. His heart was racing; his scalp felt cool and abruptly too small to cover his skull; he could feel the surge of adrenaline behind his eyes. Human eyes really did bug out when fear was extreme, he knew; they did not just widen but actually bulged as blood pressure climbed and the hydrostatic pressure of the cranial fluids increased [6, c. 20].

Уривок демонструє психологічний стан героя, зокрема прикметники confused i frightened, метафора surge of adrenaline, персоніфікації heart was racing $i$ blood pressure climbed $є$ яскравими прикладами. Автор використовує емфатичну конструкцію з дієсловом do у формі минулого часу 3 метою емоційного посилення фрази. Похолодання шкіри, прискорене серцебиття, зростання кров'яного тиску й розширення зіниць описують стан Луїса, його тривогу й страх.

Одного дня Джад відвів сім'ю Крідів на кладовище домашніх тварин. У цей момент вперше у творі підіймається тема смерті. Наступного дня Еллі була стурбована, їй наснився кошмар про смерть їі улюбленого кота Черча. Дівчинка подумки уявила, що іï улюбленець може померти: "I don't want Church to be like all those dead pets!" she burst out, suddenly tearful and furious. "I don't want Church to ever be dead! He's my cat! He's not God's cat! Let God have His own cat! Let God have all the damn old cats He wants, and kill them all! Church is mine!" Таке своєрідне обурення Еллі фактом смерті підтверджують прикметники “«tearful”, "furious", дієслово "burst out". На синтаксичному рівні спостерігається паралелізм синтаксичних структур із повторами. Луїсу довелося запевнити дочку, що смерть - це природно: “Honey, " he said, "it happens. It's a part of life" [6, c. 34].

Рейчел була не в захваті від того, що ії дочка почала цікавитися темою смерті. Через трагічну 
подію в дитинстві Рейчел вона ніколи не підіймала таку тему в родині. Ї̈̈ сестра Зельда страждала від спинного менінгіту, а маленькій Рейчел часто доводилося дбати про неї. Сестра померла, а неприйняття смерті й страх перед нею залишилися з Рейчел назавжди. Вона відмовлялася обговорювати це $з$ ким би то не було й уникала відвідування похорон.

У перший робочий день Луїса в університеті сталася смерть студента, яка теж залишила своєрідний слід у його душі. Це був Віктор Паскоу, якого збила машина під час ранньої пробіжки. Хоча Крід і Паскоу були незнайомі, свої останні слова Віктор адресував саме Кріду:

Horror rolled through Louis, gripping his warm heart in its cold hands, squeezing. It reduced him, made him less and less, until he felt like taking to his heels and running from this bloody, twisted, speaking head on the floor of the infirmary waiting room [6, c. 53].

Доктор приголомшений. Прояв схвильованості й знервованості персонажа відбувається внаслідок використання автором персоніфікації "horror rolled through", антитези warm - cold, епітетів bloody, twisted, speaking head. Тієї ж ночі мрець приходить до головного героя уві сні й веде його на кладовище домашніх тварин.

Up ahead, Pascow was only a moving shadow, and now Louis's terror seemed to have crystallized into a bright sculpture in his mind: I am following a dead man into the woods, I am following a dead man up to the Pet Sematary, and this is no dream. God help me, this is no dream. This is happening [6, с. 60]. Луїс відчуває страх та усвідомлює абсурдність ситуації. Це підтверджують повтори й паралелізм синтаксичних структур, що передають тривожний стан і створюють психоемоційне тло твору. У головного героя широко розплющені очі, він відчуває сльози на щоках і намагається стримати крик: His eyes grew wide, and he crammed his knuckles against his mouth. There was coolness on his cheeks, and he realized that in the extremity of his terror he had begun to weep [6, c. 61].

Прокинувшись вранці, він побачив бруд на своїх ногах і соснові голки. Він не міг повірити, що це був не сон. His heart leaped up in his throat like a crazy jack-in-the-box. Moving fast, eyes bulging, teeth clamped unfeelingly on his tongue, he kicked the covers all the way back [6, с. 64]. Використання персоніфікації та порівняння в реченні реалізують стан нервового напруження головного героя. Фізичний прояв емоційного стану, а саме пришвидшення серцебиття, проілюстровано через стилістичний прийом порівняння "His heart leaped up in his throat like a crazy jack-in-the-box". Jack-in-the-box, популярна американська іграшка, лежить в основі фразеологізму. Вона допома- гає уявити, наскільки сильним було хвилювання головного героя. Фрази "eyes bulging”, "teeth clamped unfeelingly on his tongue", "he kicked the covers all the way back” детально демонструють, що Луїс відчуває страх. Він приголомшений, оскільки не розуміє, чи то був сон, чи все це відбувалося наяву.

У День подяки Черча, улюбленця сім'ї, переїжджає вантажівка. Рейчел 3 дітьми гостює в іiі батьків, а труп знаходить Луїс. Він у розпачі, бо не хоче, щоб його дочка Еллі дізналася про смерть свого улюбленця, а брехати про те, що кіт загубився, Луїс не може. Попри те, що Джад має добрі наміри, він виступає як змій-спокусник, який підштовхує Луїса на гріх. Не бажаючи засмутити Еллі, Луїс із Джадом поховали кота на справжньому кладовищі, де індіанці ховали померлих.

Черч повертається живим, і Луїс зауважує зміни не тільки в зовнішності, але й у поведінці кота: Church had been dead, that was one thing; he was alive now and that was another; there was something fundamentally different, fundamentally wrong about him, and that was a third. Something had happened [6, с. 125]. Стівен Кінг використовує паралелізм синтаксичних структур, антитезу, повтори. Коли Еллі повернулася додому з мамою та братом, вона помітила, що з котом щось не так і він змінився. Вона більше не хотіла гладити його й спати 3 ним на одному ліжку.

Центральною в романі є смерть сина Луїса Гейджа, який потрапив під колеса вантажівки. Луїс не зміг змиритися зі смертю сина і вирішив воскресити його. Окрім того, що головний герой не тямить себе від горя, батьки його дружини звинувачують його в смерті маленького Гейджа: "You made my wonderful daughter into a scullery maid... destroyed her future took her away... and let my grandson die a dirty death in a country road" [6, c. 193].

Присутне в уривку умовчання створюється за допомогою пунктуації, яка $\epsilon$ елементом інформативності синтаксичного рівня. Зокрема, три крапки позначають переривання мовлення та виражають знервованість, схвильованість, сум і розпач у душі батька Рейчел, що заважають закінчити висловлювання.

Луїс зловив себе на думці, що ще у вересні він знав, що його син загине, ще тоді він відчув передвісники смерті: <..> When he took Gage upstairs a horrible premonition had struck him, and now he understood: Back in September part of him had known Gage was going to die soon [6, c. 202]. Персоніфікація "horrible premonition had struck him” ніби «олюднює» відчуття страху, створює атмосферу напруги у творі.

Головний герой не зміг змиритися зі смертю сина. Дивне запитання саме собою виникло в 
його голові. Воно було таким простим і природним, що, здавалося, весь час було там, у глибині його свідомості: When are you going to do it? When are you going to bury Gage in the annex to the Pet Sematary? [6, c. 201].

У роздумах, чи ховати свого сина на кладовищі домашніх тварин, Луїс міркує про Черча. Риторичні питання ілюструють його відчай і безвихідь: At least tell yourself the goddamned truth about the change in Church. Even if you want to disqualify the animals - the mice and the birds - what about the way he is? Muddled $<\ldots>$ that's the best word of all, that sums it up. The day we were out with the kite. You remember how Gage was that day? How vibrant and alive he was, reacting to everything? Wouldn't it be better to remember him that way? [6, с. 230].

Головний герой не може раціонально й адекватно думати. Смерть близької людини виявилась занадто важкою для нього. У його душі лише відчай і відчуття провини. Луїс вирішує відправити Еллі й Рейчел із бабусею та дідусем у Чикаго, а за час їх відсутності воскресити Гейджа. У глибині душі Рейчел підозрює щось недобре. У літаку Еллі прокинулась збуджена й стурбована. Вона кричала знову й знову: It's Gage! Mommy! It's Gage! it's Gage! Gage is alive! Gage has got the knife from Daddy's bag! Don't let him get me! Don't let him get Daddy! [6, с. 251]. Паралелізм, повтори й пунктуація передають тривожний психологічний стан дівчинки. Уві сні до неї прийшов Паскоу й попередив, що трапиться щось жахливе.

Після того, як Луїс ховає сина на кладовищі домашніх тварин, Гейдж повертається зовсім іншим. Це вже не маленький світлий хлопчик, а справжнє чудовисько. Він вбиває власну матір і Джада, i це змушує Луїса вбити сина, якого він власноруч воскресив.

Здавалося б, тепер Луїс має винести урок із цього випадку, але він вирішує поховати свою дружину на кладовищі домашніх тварин. Він не тямить себе від горя, щиро думаючи, що на цей раз спроба виявиться вдалою: "I waited too long with Gage," Louis said. "Something got into him because I waited too long. But it will be different with Rachel, Steve. I know it will" [6, c. 330].

Висновки й перспективи подальших розробок. Як свідчить проведений аналіз, С. Кінг досить детально передає емоційний стан персонажів на сторінках свого роману. Найчастіше емоційні стани виражаються комплексом лінгвостилістичних засобів, серед яких епітети, метафори, персоніфікації, повтори, паралелізм, умовчання тощо. Вираження емоцій страху, жаху, тривоги, невизначеності, хвилювання створюються за допомогою лексичних одиниць, зокрема "horror", "terror", "terrible", "horrible" тощо. Опис емоційного стану героїв допомагає досягти емпатії 3 боку читача. Таким чином, автор залучає читача до активного співпереживання героям, відбувається емоційне включення читача в текстову дійсність.

Перспективою дослідження може стати вивчення способів відтворення емоцій персонажів літератури жахів під час перекладу.

\section{ЛІТЕРАТУРА}

1. Гудманян А.Г., Іванова А.О. Генеза та жанрові особливості літератури жахів з позицій сучасної науки про переклад. Гуманітарна освіта в технічних вищих навчальних закладах. 2017. Вип. 36. С. 12-17.

2. Zillmann D, Hay T.A., Bryant J. The effect of suspense and its resolution on the appreciation of dramatic presentations. Journal of Research in Personality. 1975. No. 9. P. 307-323.

3. Джемс У. Психология. Москва : Педагогика, 1991. $369 \mathrm{c}$.

4. Седых А.П. Природа эмоций и их классификация в гуманитарных науках и языкознании. Научные ведомости Белгородского государственного университета. Гуманитарные науки. 2010. № 6 (125). Т. 13. С. 108-115.

5. Шаховский В.И. Лингвистическая теория эмоций : монография. Москва : Гнозис, 2008. C. 13-259.

6. King S. Pet Sematary. URL: http://allking.club/ books/pet_sematary/ (дата звернення: 20.09.2021).

\section{REFERENCES}

1. Hudmanian, A., Ivanova, A. (2017) Heneza ta zhanrovi osoblyvosti literatury zhakhiv z pozytsii suchasnoi nauky pro pereklad [Genesis and genre peculiarities of horror literature from perspective of contemporary translation studies]. Humanities education in technical higher educational institutions, vol. 36, pp. 12-17.

2. Zillmann, D, Hay, T.A., Bryant, J. (1975) The effect of suspense and its resolution on the appreciation of dramatic presentations. Journal of Research in Personality, 9, pp. 307-323.

3. James, W. (1991) Psihologiya [Psychology]. (L. Petrovska, Trans.) M.: Pedahohyka. [in Russian].

4. Sedykh, A.P. (2010) Priroda emotsiy i ikh klassifikatsiya $\mathrm{v}$ gumanitarnykh naukakh i yazykoznanii [The nature of emotions and their classification in the humanities and linguistics]. Scientific statements of BelSU, Humanities, vol. 6 (125), pp. 108-115.

5. Shakhovsky, V.I. (2008) Lynhvystycheskaia teoryia emotsyi [Linguistic theory of emotions]. M.: Hnozys. [in Russian].

6. King, S. Pet Sematary. URL: http://allking.club/ books/pet_sematary/ (accessed 20 September 2021). 